\title{
Proposal for Rectifying a Chaotic Educational System in a Third World Country
}

\author{
Seun Ayoade* \\ Independent Researcher, Alumnus, College of Medicine University of Ibadan, Oyo State, Nigeria \\ *Corresponding author: Seun Ayoade, Independent Researcher, Alumnus, College of Medicine University of Ibadan, Oyo \\ State, Nigeria
}

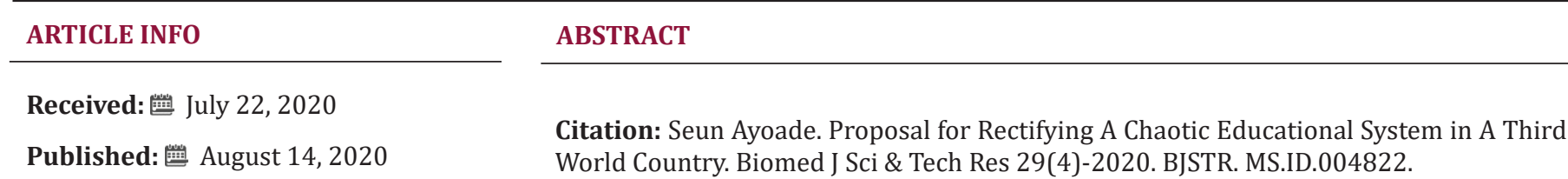

\section{Opinion}

Public education in Nigeria is a clumsy, cumbersome process with perennial and protracted ASUU [1], NASU [2] and SSANU [3] strikes. As a result, many students are full grown women and men-in the true sense of the term-when they eventually graduate. Since this third world country has an abysmally low doctor to patient ratio and generally poor health care I recommend a radical reorganization of its medical and entire tertiary education system thus-

1. Current five year Bachelor of Pharmacy should be scrapped. Instead pharmacy education should follow the tiered Indian method [4] viz- Two year diploma for those who want to own or work in pharmacies whether private or government owned. Four year Bachelor degree for those who want to work in the pharmaceutical industry and a five year Bachelor degree for those who want to go into academia.

2. Training in optometry and radiography should be downgraded from four year Bachelor degrees to two year diplomas. I honestly don't think anyone needs four years to learn how to take $\mathrm{X}$ rays, operate MRI machines, do CAT scans, sight test and recommend glasses.

3. Under this new system all superfluous teaching material must be jettisoned for a lean, efficient system. The mandatory GES (General Studies) must be scrapped, and a Bachelor of General Studies degree created for those interested in such studies- to prevent the onerous departments and staff thereof from going fully moribund. 4. The current onerous and lugubrious six year MBBS (Bachelor of Medicine and Bachelor of Surgery degree) should be diversified to include a 3 to 4 year Licentiateship in Medicine and Surgery (Physician Assistant Equivalent) [5].

5. Similarly all five or four year Bachelor degrees (Bachelor of Laws, Science, Arts and Education i.e. LLB, BSc, BA and Bed) should be trimmed to three year Bachelor degrees as obtains in the United Kingdom. The Nigerian law school should be abrogated and completely scrapped.

If all the above recommendations are followed there is no doubt there will be a huge improvement in public health and socio economic progress.

\section{References}

1. Academic Staff Union of Universities.

2. Non-academic Staff Union of Universities.

3. Senior Staff Association of nigerian Universities.

4. Basak SC, Sathyanarayana D (2010) Pharmacy Education in India. Am J Pharm Educ 74(4): 68.

5. Mister SA (2017) Returning the Physician Assistant Profession to its Roots Could Ease the Tension; Reduce Animosity between Physician Assistants and Others. Meanwhile, a Third World Country Needs Physician Assistants. JOJ Nurse Health Care 4(1): 555630. 


\section{ISSN: 2574-1241}

DOI: 10.26717/BJSTR.2020.29.004822

Seun Ayoade. Biomed J Sci \& Tech Res

(C) (i) This work is licensed under Creative

Submission Link: https://biomedres.us/submit-manuscript.php

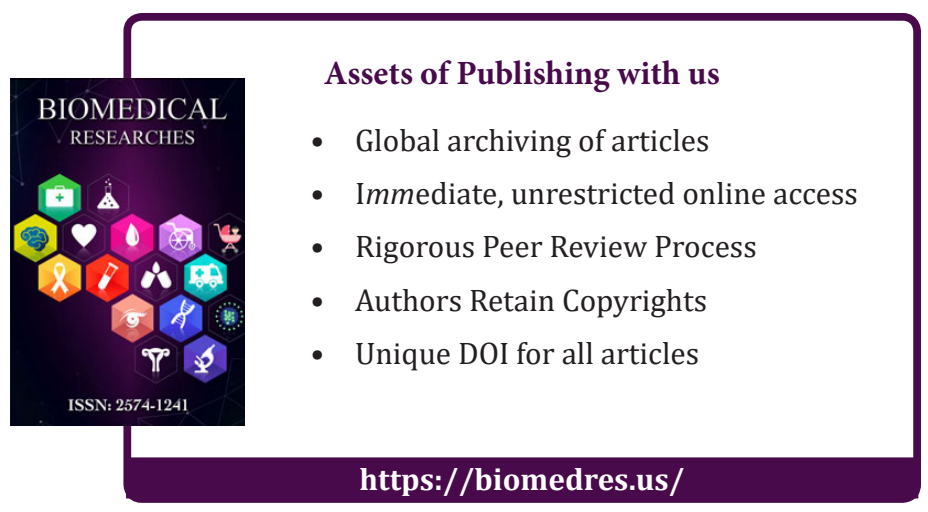

